\title{
Differential Pulse Polarographic Behavior and Quantification of the Flucloxacillin in Pure and Pharmaceutical Dosage Forms Using a Static Mercury Drop Electrode
}

\author{
Abdul Aziz Ramadan ${ }^{1 *}$, Hasna Mandil ${ }^{2}$, Reham Abu-Saleh \\ Department of Chemistry, Faculty of Science, University of Aleppo, Syria. \\ ${ }^{*}$ E-mail: dramadan@scs-net.org, ${ }^{2}$ E-mail: promandil955@gmail.com
}

\begin{abstract}
Differential pulse polarographic analysis (DPPA) by using static mercury drop electrode (SMDE) for quantification of flucloxacillin (FLUX) in pure and pharmaceutical dosage forms was studied. The optimum conditions for the polarographic signal of the different parameters affecting the electrochemical process were determined. The best definition of the analytical signals was found in Britton Robinson buffer $(0.06 \mathrm{M})$ at $\mathrm{pH}$ 4.0. Under the optimum conditions, liner calibration graph, $I_{p}=f\left(C_{F L U X}\right)$, was obtained in the concentration ranges of $0.1 \mu \mathrm{M}\left(0.0494 \mu \mathrm{g} \cdot \mathrm{mL}^{-1}\right)$ to $26 \mu \mathrm{M}\left(12.8414 \mu \mathrm{g} \cdot \mathrm{mL}^{-1}\right)$ at -940 to $-1000 \mathrm{mV}$ (versus $\mathrm{Ag} / \mathrm{AgCl}$ ) with relative standard deviations (RSD) did not exceed $2.4 \%$ for the concentrations of FLUX $\left(0.0494 \mu \mathrm{g} \cdot \mathrm{mL}^{-1}\right)$. Regression analysis showed a good correlation coefficient $\left(R^{2}=9998\right)$ between $I_{p}$ and concentration over the mentioned range. The limit of detection (LOD) and the limit of quantification (LOQ) were to be 0.0040 and $0.0120 \mu \mathrm{g} \cdot \mathrm{mL}^{-1}$, respectively. The proposed method was validated for linearity, precision and accuracy, repeatability, sensitivity (LOD and LOQ), robustness and specificity. The developed method is applicable for the determination of FLUX in pure and different dosage forms in presence a same amount of amoxicillin (AMOX) with average recovery of 99.4 to $102.2 \%$ and the results are in good agreement with those obtained by the HPLC reference method.
\end{abstract}

Keywords: Differential pulse polarography; static mercury drop electrode, Flucloxacillin

Date of Submission: 2018-07-16

Date of Acceptance: 2018-08-26

Date of Publication: 2018-08-30

DOI 10.24297/jac.v15i2.7529

ISSN: 2321-807X

Volume: 15 Issue: 02

Journal: Journal of Advances in Chemistry

Website: https://cirworld.com

This work is licensed under a Creative Commons Attribution 4.0 International License. 


\section{INTRODUCTION}

Flucloxacillin [3-(2-chloro-6-fluorophenyl)-5-methylisoxazol-4-yl] carbonyl] amino]-3,3dimethyl -7-oxo-4-thia1 -azabicyclo [3. 2.0] heptane 2-carboxylate] are the penicillinase-resistant penicillins. It is used as an antibiotic [1]. It is normally synthesized for use pharmaceutically usually as the sodium salt and less so, the magnesium salt $[2,3]$. Freely soluble in water and in methanol. The chemical formula of flucloxacillin sodium is $\mathrm{C}_{19} \mathrm{H}_{16} \mathrm{ClFN}_{3} \mathrm{NaO}_{5} \mathrm{~S} . \mathrm{H}_{2} \mathrm{O}$, its molecular weight is $493.9 \mathrm{~g} \cdot \mathrm{moL}^{-1}$. The chemical structure of flucloxacillin sodium showed in scheme 1.

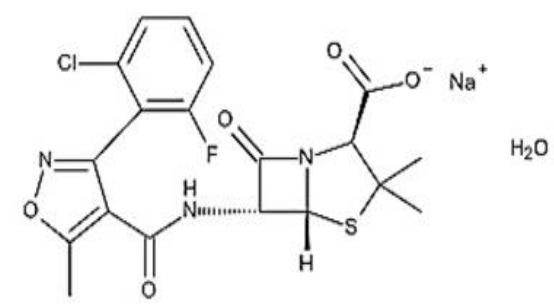

Scheme 1: Chemical structure of Flucloxacillin.

The hydrolysis of flucloxacillin at $\mathrm{pH} 4.9$ yields a degradation product which is polarographically oxidizable. It gives a diffusion-controlled anodic polarographic wave with a half-wave potential at $-0.24 \mathrm{~V}$ (versus $\mathrm{Ag} / \mathrm{AgCl}$ ) [4]. A potentiometric method for determination of flucloxacillin is developed. The method involves development of a flucloxacillin sensor with a membrane consisting of Aliquat flucloxacillin as an electro active material in poly vinyl chloride matrix membrane plasticized with ortho nitro phenyl-octyl ether or dioctylphthalate. The sensor shows fast, stable and reproducible response over the concentration range of $1.0 \times 10^{-5}-1.0 \times 10^{-2} \mathrm{M}$ flucloxacillin and $\mathrm{pH}$ ranges of 6-11 and 7-11 for o-nitro phenyl octyl ether and dioctylphthalate plasticized based membrane sensors, respectively [5].

The separation was made by a ZORBAX 300-SCX column using $0.025 \mathrm{M}$ ammonium dihydrogen phosphate (adjusted to $\mathrm{pH} 2.6$ with phosphoric acid)-acetonitrile (95:5) as mobile phase [6]. A simple, precise, fast and accurate HPLC method has been developed for the simultaneous estimation amoxicillin and flucloxacillin in capsules. The analytes were resolved, by using a mobile phase mixture of buffer (prepared from $0.001 \mathrm{M}$ diammonium hydrogen orthophosphate and $0.04 \mathrm{M}$ tetra butyl ammonium bromide $\mathrm{pH}$ adjusted to $7.0 \pm 0.1$ with ortho phosphoric acid) and acetonitrile in the ratio $(90: 10, \mathrm{v} / \mathrm{v})$, on a strong cation exchange column, (LUNA SCX, $250 \mathrm{~mm} \times 4.6 \mathrm{~mm}$ I.D. $5 \mu \mathrm{m}$ particles).The retention times for amoxicillin and flucloxacillin were found to be 3.828 and $5.89 \mathrm{~min}$, respectively [7].

On the other hand, there are several methods available in the literature for the quantification of flucloxacillin including high performance liquid chromatography [6-12], spectrophotometry [13-16] and nuclear magnetic resonance spectrometry [17].

The SMDE used successfully in polarographic analysis. The SMDE combines the features of the dropping mercury electrode (DME) and hanging mercury drop electrode (HMDE): As with the DME, the drops are constantly renewed, but during the measurement the drop area is constant as in the HMDE case. In a subsequent voltage $(U)$ sweep, the $\mathrm{Hg}$ drops are knocked off by the tapping mechanism after the time $\mathrm{t}$. step set in the measurement mode. The SMDE is primarily used for sensitive measurements in which the surface of the mercury drop must be renewed for every measurement [18]. 
In the present work, differential pulse polarographic behavior and quantification of the flucloxacillin in pure and pharmaceutical dosage forms using a static mercury drop electrode was applied. The method is an easy, fast and sensitive for the determination this compound in pure and in pharmaceuticals.

\section{MATERIALS AND METHODS}

\subsection{Equipment and Materials}

A Metrohm 746 VA processor, A Metrohm 747 VA stand with a static mercury drop electrode (SMDE) as a working electrode, an auxiliary platinum electrode and a reference electrode, double junction type, $(\mathrm{Ag} / \mathrm{AgCl})$ saturated with a $3.0 \mathrm{M} \mathrm{KCl}$ solution and the three-electrode cell were used. All measurements were done at room temperature $25 \pm 5^{\circ} \mathrm{C}$. Highly pure nitrogen gas ( $\left.99.999 \%\right)$ was used for de-oxygenation. $\mathrm{pH}$ meter from Radiometer company model ion check was used for the studying and monitoring the $\mathrm{pH}$ effects. The diluter pipette model DIP-1 (Shimadzu), having $100 \mu \mathrm{L}$ sample syringe and five continuously adjustable pipettes covering a volume range from 20 to $5000 \mu \mathrm{L}$ (model PIPTMAN P, GILSON), were used for preparation of the experimental solutions. An ultrasonic processor model Powersonic 405 was used to sonicate the sample solutions. Electronic balance (Sartorius-2474; $\mathrm{d}=0.01 \mathrm{mg}$ ) was used for weighing the samples.

Working reference standard of flucloxacillin (99.2\%) was supplied by D.K. Pharma chem. Pvt. Ltd INDIA, (Mfg.12-2017, Exp. 11-2020). Lithium perchlorate trihydrate, di-Sodium hydrogen phosphate dodecahydrate, Sodium chloride, Sodium hydroxid, Perchloric acid (70\%), ortho-Phosphoric acid (85\%), Acetic acid (100\%), Boric acid (100\%) were of GR for analysis purchased from MERCK.

Commercial formulations (as capsule) were used for the analysis of FLUX by using DPPA with SMDE. The pharmaceutical formulations were subjected to the analytical procedures:

(1) Amoxipen capsule, BARAKAT PHARMACEUTICAL, Aleppo-SYRIA, each capsule contains: $250 \mathrm{mg}$ of FLUX and $250 \mathrm{mg}$ AMOX (Exp. 03.2020).

(2) Amoxam capsule, IBN HAYYAN, Homs -SYRIA, each capsule contains: $250 \mathrm{mg}$ of FLUX and $250 \mathrm{mg}$ AMOX (Exp. 06.2020).

(3) Penifloxam capsule, APHAMEA, Hama-SYRIA, each capsule contains: $250 \mathrm{mg}$ of FLUX and $250 \mathrm{mg}$ AMOX (Exp. 04.2020).

(4) Floxin capsule, ALBALSAM PHARMA, Homs- SYRIA, each capsule contains: $250 \mathrm{mg}$ of FLUX and $250 \mathrm{mg}$ AMOX (Exp. 04.2020).

(5) Maxipen capsule, ASIA, Aleppo-SYRIA, each capsule contains: $250 \mathrm{mg}$ of FLUX and $250 \mathrm{mg}$ AMOX (Exp. 06.2020).

\subsection{Standard stock solutions}

\subsubsection{A stock standard solution of flucloxacillin $\left(1 \times 10^{-4} \mathrm{~mol}^{-\mathrm{L}^{-1}}\right)$}

This solution was prepared by dissolving $49.79 \mathrm{mg}$ from flucloxacillin in $100 \mathrm{~mL}$ double distilled deionized water $\left(1 \times 10^{-3} \mathrm{~mol}^{\mathrm{L} \mathrm{L}^{-1}}\right)$, then dilute $10.000 \mathrm{~mL}$ from this solution to $100 \mathrm{~mL}\left(1 \times 10^{-4} \mathrm{~mol} . \mathrm{L}^{-1}\right)$.

\subsubsection{Supporting electrolyte}

Britton Robinson, $\mathrm{H}_{3} \mathrm{PO}_{4}-\mathrm{Na}_{2} \mathrm{HPO}_{4}$, lithium perchlorate, sodium chloride as supporting electrolytes (buffers) $0.200 \mathrm{~mol}^{-\mathrm{L}^{-1}}$ at $\mathrm{pH}$ (2.5-9.0) were used. 


\subsection{Recommended Procedure}

The stock solutions were further diluted to obtain working solutions daily just before use in the ranges of FLUX: $0.100,0.200,0.300,0.400,0.800,1.000,2.000,4.000,8.000,12.000,16.000,20.000,22.000,24.000$ and $26.000 \mu \mathrm{mol}^{-\mathrm{L}^{-1}}(0.0494,0.0988,0.1482,0.1976,0.3951,0.4939,0.9878,1.9756,3.9512,5.9268,7.9024,9.8780$, $10.8780,11.8658$ and $12.8414 \mu \mathrm{g} \cdot \mathrm{mL}^{-1}$ ) by dilution of the volumes: $0.025,0.050,0.075,0.100,0.200,0.250$, $0.500,1.000,2.000,3.000,4.000,5.000,5.500,6.000$ and $6.500 \mathrm{~mL}$ from stock standard solutions were transferred into $25 \mathrm{~mL}$ volumetric flask. $7.5 \mathrm{~mL}$ of supporting electrolyte were added, and diluted with double distilled deionized water to the mark. Ultrapure mercury from Metrohm Company was used throughout the experiments.

\subsection{Procedure for pharmaceutical formulations}

Contents of 20 capsules of each studied pharmaceutical formulations were weighted accurately, crushed to a fine powder and mixed well. Equivalent weight of contents of one capsule, was solved in $50 \mathrm{~mL}$ double distilled deionized water by using ultrasonic, filtered over a $100 \mathrm{~mL}$ flask and diluting to $100 \mathrm{~mL}$ with double distilled deionized water, which content as the follows: $2500 \mu \mathrm{g} \cdot \mathrm{mL}^{-1}$ for all studied pharmaceutical formulations content $250 \mathrm{mg} / \mathrm{cap}$.

These solutions were prepared daily by diluting $100 \mu \mathrm{L}(0.100 \mathrm{~mL})$ from stock solutions of pharmaceutical formulations, adding $30 \mathrm{~mL}$ from supporting electrolyte, then diluting to $100 \mathrm{~mL}$ with double distilled deionized water (each solution contents $2.5 \mu \mathrm{g} \cdot \mathrm{mL}^{-1}$ of FLUX).

\subsection{Analytical procedure}

$25 \mathrm{~mL}$ of working standard of flucloxacillin or working solutions of pharmaceuticals was transferred to the cell. The solution was deoxygenated with $\mathrm{N}_{2}$ gas for $300 \mathrm{~s}$. The potential range studied was from -400 to $-1400 \mathrm{mV}$ (versus $\mathrm{Ag} / \mathrm{AgCl}$ ) with differential pulse polarographic analysis using static mercury drop electrode in the optimum conditions were applied.

\section{RESULTS AND DISCUSSION}

\subsection{Differential pulse polarographic behavior}

The polarograms for concentration $0.10-26.0 \mu \mathrm{mol} . \mathrm{L}^{-1}\left(0.0494-12.8414 \mu \mathrm{g} \cdot \mathrm{mL}^{-1}\right)$ of FLUX in the optimal conditions (supporting electrolytes, $\mathrm{pH}$, scan rate, initial potential, final potential, ...etc.) using DPPA at SMDE were studied. The best definition of the analytical signals was found in Britton Robinson $(0.06 \mathrm{M})$ buffer $(\mathrm{pH}$ 4.0) at -940 to $-1000 \mathrm{mV}$ (versus $\mathrm{Ag} / \mathrm{AgCl}$ ).

\subsection{The effect of supporting electrolytes (buffer)}

The electrochemical behavior of flucloxacillin was studied in various supporting electrolytes such as (Britton Robinson, di-sodium hydrogen phosphate dodecahydrate, lithium perchlorate trihydrate, sodium chloride) was studied at $\mathrm{pH}$ (2.5-9.0). The best definition of the analytical signals was found in Britton- Robinson buffer $\left(\mathrm{pH}\right.$ 4.0) at concentration $0.06 \mathrm{M}$. The effect of supporting electrolytes (buffer) on the $I_{p}$ and $E_{p}$ was studied. The values of $E_{p}$ were $-968,-965,-893$ and $-890 \mathrm{mV}$ for the mentioned buffers, respectively, see Figure 1 . The effect of the concentration of Britton Robinson was tested over the 4, 8, 10, 20, 30, 35, 40,50,60, 70, 80, 90 and $100 \mathrm{mM}$. The DPPA at SMDE of $8.0 \mu \mathrm{M}$ of FLUX with the varying mentioned concentrations of supporting electrolyte was studied. The values of $I_{p}$ increase with increasing concentration of supporting electrolyte of 4 to $50 \mathrm{mM}$, then become semi-fixed until concentration of supporting electrolyte $100 \mathrm{mM}$, while Ep remains quasi-static. 


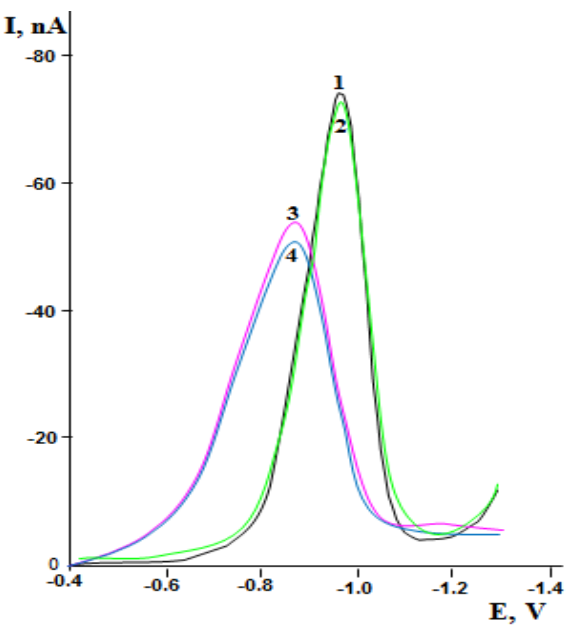

Fig.1: The effect of buffer solutions on polarograms of FLUX $(8.00 \mu \mathrm{M})$ using DPPA at SMDE buffers $(0.06 \mathrm{M})$ at $\mathrm{pH}$ 4.0: 1 - Britton Robinson, 2- $\mathrm{Na}_{2} \mathrm{HPO}_{4} \cdot 12 \mathrm{H}_{2} \mathrm{O}, 3-\mathrm{NaCl}$, 4- $\mathrm{LiClO}_{4} \cdot 3 \mathrm{H}_{2} \mathrm{O}$ (Purge gas $\mathrm{N}_{2}$, purge time $300 \mathrm{~s}$, sweep rate $4 \mathrm{mV} / \mathrm{s}$, U. amplitude $-100 \mathrm{mV}$, t. meas $32 \mathrm{~ms}$, t. pulse $35 \mathrm{~ms}$, t. step $2 \mathrm{~s}$, U. step $8 \mathrm{mV}$, drop size 9 , temperature $25^{\circ} \pm 5^{\circ} \mathrm{C}$ ).

\subsection{The effect of $\mathrm{pH}$}

The influence of $\mathrm{pH}$ from 2.5 to 9.0 using Britton Robinson $(0.06 \mathrm{M})$ buffer on $I_{p}$ and $E_{p}$ was studied. The values of $I_{p}$ increase with increasing $\mathrm{pH}$ value of 2.5 to 4.0 , then decrease until $\mathrm{pH} 6.0$ and finally become semi-fixed until $\mathrm{pH} 9.0$. While $\mathrm{E}_{\mathrm{p}}$ values are growing a positive value from $-1075 \mathrm{mV}$ (when $\mathrm{pH} 2.5$ ) to $-910 \mathrm{mV}$ (when pH 5.0) then become semi-fixed until pH 9.0, see Figures 2,3.

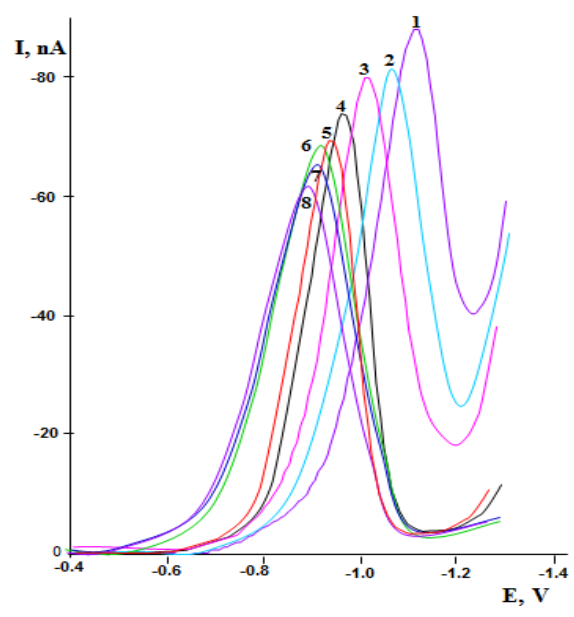

Fig.2: The effect of pH solution on polarograms of FLUX $(8.00 \mu \mathrm{M})$ using DPPA at SMDE at pH: 1- 2.5; 2- 3.0; 3- 3.5; 4- 4.0; 5- 4.5; 6- 5.0; 7- 6.0 and 8- 9.0 using Britton Robinson buffer ( $0.06 \mathrm{M})$. (Purge gas $\mathrm{N}_{2}$, purge time $300 \mathrm{~s}$, sweep rate $4 \mathrm{mV} / \mathrm{s}$, U. amplitude $-100 \mathrm{mV}$, drop size 9 , t. meas $32 \mathrm{~ms}$, t. pulse $35 \mathrm{~ms}$, t. step $2 \mathrm{~s}$, U. step 8 $\mathrm{mV}$, temperature $25^{\circ} \pm 5^{\circ} \mathrm{C}$ ). 

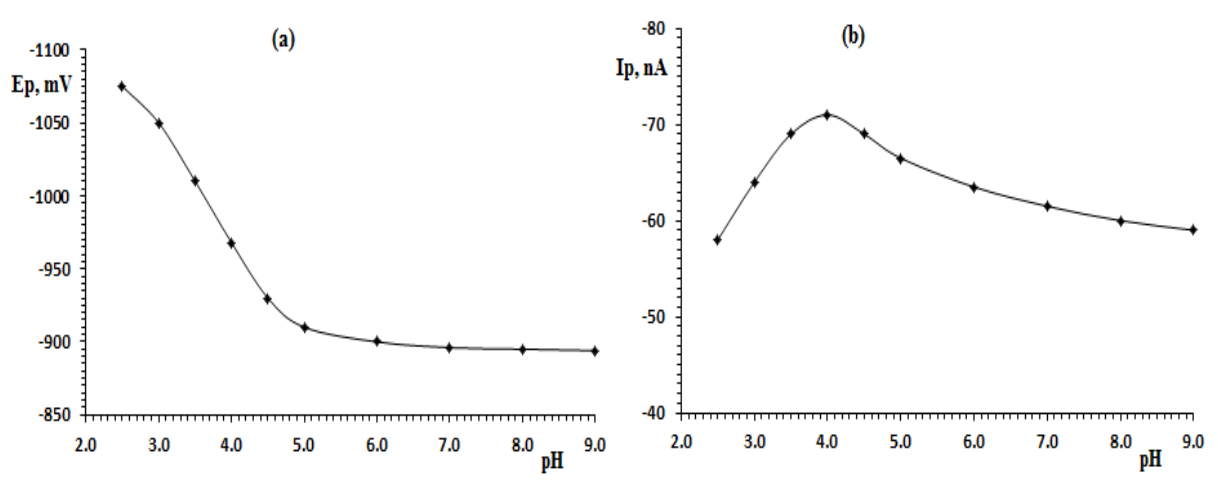

Fig.3: The effect of $p H$ solution on $E_{p}(a)$ and $I_{p}(b)$ of FLUX $(8.00 \mu M)$ using DPPA at SMDE containing buffer Britton Robinson $\left(0.06 \mathrm{M}\right.$ ) (Purge gas $\mathrm{N}_{2}$, purge time $300 \mathrm{~s}$, sweep rate $4 \mathrm{mV} / \mathrm{s}$, U. amplitude $-100 \mathrm{mV}$, drop size 9 , t. mesa $32 \mathrm{~ms}$, t. pulse $35 \mathrm{~ms}$, t. step $2 \mathrm{~s}$, U. step $8 \mathrm{mV}$, temperature $25^{\circ} \pm 5^{\circ} \mathrm{C}$ ).

\subsection{The effect of negative pulse amplitude (U. ampl)}

The effect of negative pulse amplitude ( $U$. ampl) between -10 to $-100 \mathrm{mV}$ on $I_{p}$ and $E_{p}$ was studied. $I_{p}$ linearly increases with increasing amplitude value until $-100 \mathrm{mV}$. While $E_{p}$ stay semi-fixed. The value $-100 \mathrm{mV}$ was better than another's.

\subsection{The effect of initial and final potential}

The effect of initial and final potential on the $I_{p}$ and $E_{p}$ was studied. It was found that the best initial potential was $-400 \mathrm{mV}$ and the best final potential was $-1400 \mathrm{mV}$.

\subsection{The effect of temperature and time}

The effect of temperature and time on the electrochemical behavior of FLUX was studied at different values $\left(15-35^{\circ} \mathrm{C}\right.$ and $\left.5-60 \mathrm{~min}\right)$ by continuous monitoring of the $I_{p}$. It was found that, the value of $I_{p}$ was not affected by temperature between 20 to $30^{\circ} \mathrm{C}$ (the temperature at $25 \pm 5^{\circ} \mathrm{C}$ was used). The effect of waiting time was determined at laboratory ambient temperature $\left(25 \pm 5^{\circ} \mathrm{C}\right)$. It was found that, the value of $\mathrm{I}_{\mathrm{p}}$ was not affected by time between 5 to $60 \mathrm{~min}$.

\subsection{The effect of time pulse (t. pulse)}

The effect of time pulse $(35,40,45,50,55,60,65,70,75,80,85,90,95$ and $100 \mathrm{~ms})$ on polarograms was as the follows: $I_{p}$ decreases with increasing time pulse and $E_{p}$ has become increasingly positive value ( -968 to -944 $\mathrm{mV}$ ) with increasing t. pulse. The peak was more symmetrical and $I_{p}$ was the highest when the $t$. pulse value of $35 \mathrm{~ms}$.

\subsection{The effect of time interval for voltage step (t. step)}

It found that the $I_{p}$ linearly increases with increasing taste $(0.2,0.3,0.4,0.5,0.6,0.7,0.8,0.9,1.0,1.5,2.0$ and $2.5 \mathrm{~s})$, while $E_{\mathrm{p}}$ has become increasingly positive value $(-1006$ to $-975 \mathrm{mV})$ with increasing taste. The value of the preferred $\mathrm{t}$. step was $2 \mathrm{~s}$.

\subsection{The effect of measurement time (t. meas)}

It found that the $I_{p}$ increases with increasing t. meas. $(2,4,6,8,10,12,16,20,24,28,30$, and $32 \mathrm{~ms})$, while $E_{p}$ remains quasi-static. The value of the preferred t. meas was $32 \mathrm{~ms}$. 


\subsection{The effect of drop size}

It found that the $I_{p}$ increases slightly with increasing drop size from 1 to 9 size, while $E_{p}$ stays semi-fixed with increasing drop size. The value of the preferred drop size was 9.

The optimum parameters established for determination of FLUX using DPPA on SMDE showed in Table 1.

Table 1: The optimum parameters established for determination of FLUX using DPPA on SMDE.

\begin{tabular}{|l|c|}
\hline \multicolumn{1}{|c|}{ Parameters } & Operating modes \\
\hline Working electrode & Static Mercury Drop Electrode (SMDE) \\
Supporting electrolytes (buffer) & Britton Robinson 0.06 M \\
$\mathrm{pH}$ & 4.0 \\
Solvent of flucloxacillin & double distilled deionized water \\
Purge gas & Pure $\mathrm{N}_{2}$ \\
Purge time & $300 \mathrm{~s}$ \\
Initial potential & $-400 \mathrm{mV}$ \\
Final potential & $-1400 \mathrm{mV}$ \\
Scan rate & $4 \mathrm{mV} / \mathrm{s}$ \\
t. meas & $32 \mathrm{~ms}$ \\
U. ampl & $-100 \mathrm{mV}$ \\
t. pulse & $35 \mathrm{~ms}$ \\
t. step & $2 \mathrm{~s}$ \\
Drop size & 9 \\
Temperature of solution & $25^{\circ} \pm 5^{\circ} \mathrm{C}$ \\
\hline
\end{tabular}

\section{Calibration curves}

Calibration curves for the determination of FLUX using differential pulse polarographic analysis on SMDE with negative amplitude in Britton Robinson $(0.06 \mathrm{M})$ buffer at $\mathrm{pH} 4.0$ were applied. One peak was observed in the range -940 to $-1000 \mathrm{mV}\left(E_{p}\right)$. The peak current $\left(I_{p}\right)$ was proportional to the concentration of FLUX over the range $0.0494-12.8414 \mu \mathrm{g} \cdot \mathrm{mL}^{-1}\left(0.100-26.000 \mu \mathrm{mol}^{-\mathrm{L}^{-1}}\right)$. The polarograms in the optimum conditions using DPPA at SMDE of FLUX at different concentrations are showed in Figure 4 . The regression equation was as the follows: $y=-18.191 x-0.5094, R^{2}=0.9998\left(y: I_{p}, n A\right.$ and $\left.x: C_{F L U X}, \mu g \cdot m L^{-1}\right)$, see Figure 5.

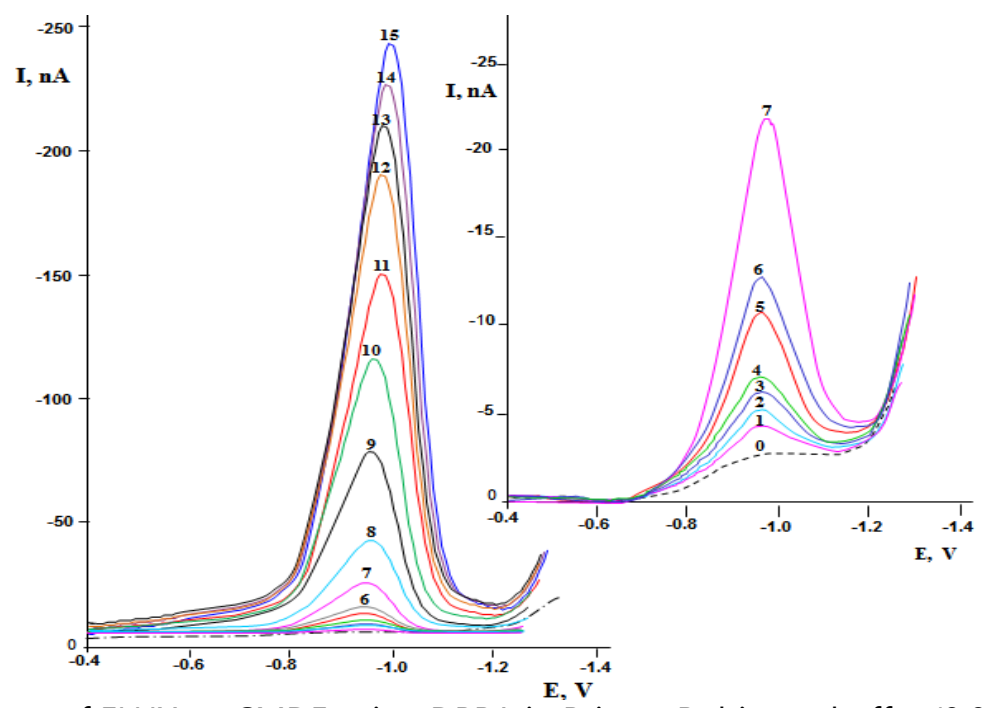

Fig.4: The polarograms of FLUX on SMDE using DPPA in Britton Robinson buffer $(0.06 \mathrm{M})$ at $\mathrm{pH} 4.0$ at

concentrations: $1-0.0494,2-0.0988,3-0.1482,4-0.1976,5-0.3951,6-0.4939$,

7- 0.9878, 8- 1.9756, 9- 3.9512, 10- 5.9268, 11- 7.9024, 12- 9.8780, 13- 10.8780, 14- 11.8658

and $15-12.8414 \mu \mathrm{g} \cdot \mathrm{mL}^{-1}$ (Purge gas $\mathrm{N}_{2}$, purge time $300 \mathrm{~s}$, sweep rate $4 \mathrm{mV} / \mathrm{s}, \mathrm{U}$. ampl -100

$\mathrm{mV}$, t. meas $32 \mathrm{~ms}$, t. pulse $35 \mathrm{~ms}$, t. step $2 \mathrm{~s}$, U. step $8 \mathrm{mV}$, drop size 9 , temperature $25^{\circ} \pm 5^{\circ} \mathrm{C}$ ). 


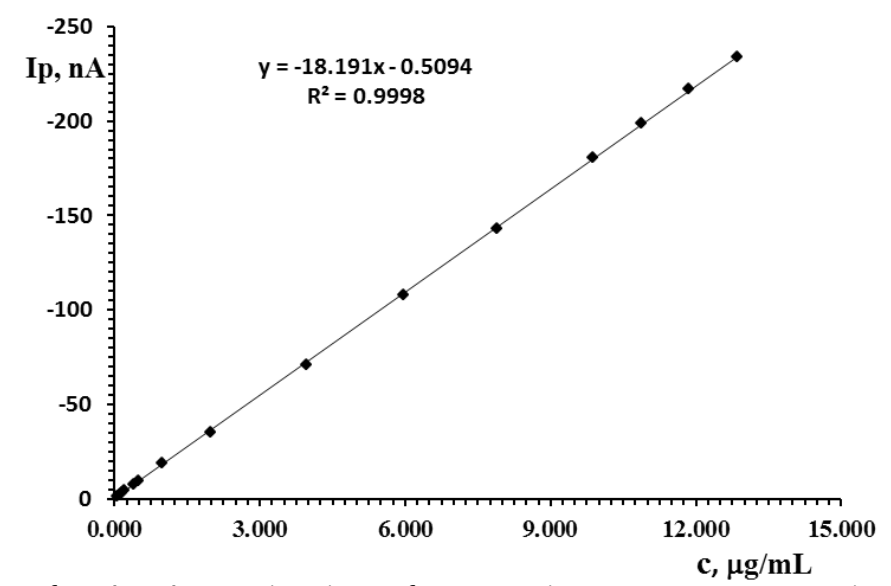

Fig.5: Calibration curves for the determination of FLUX using DPPA on SMDE in the optimum conditions

$$
\left(I_{p}=l_{p, t o t a l}-l_{\text {elect}}\right) \text {. }
$$

\section{Analytical results}

Determination of FLUX using DPPA on SMDE in the optimum conditions using analytical curves, $I_{p}=f\left(C_{F L U X}\right)$, showed that the accuracy was over the range of FLUX concentration between (0.0494-12.8414 $\left.\mu \mathrm{g} \cdot \mathrm{mL}^{-1}\right)$. The relative standard deviation (RSD) not more than $2.4 \%$, see Table 2. Limit of detection (LOD) and limit of quantitation (LOQ) for the determination of FLUX by this method were as the follows: 0.0040 and 0.0120 $\mu \mathrm{g} \cdot \mathrm{mL}^{-1}$, respectively.

Table 2: Determination of flucloxacillin using differential pulse polarographic analysis on SMDE with negative amplitude in Britton Robinson (0.06M) buffer at pH 4.0.

\begin{tabular}{|c|c|c|c|c|c|c|}
\hline \multicolumn{2}{|c|}{ Taken $\mathbf{x}_{\mathbf{i}}$} & \multirow[b]{2}{*}{$\begin{array}{c}\text { Found } \\
{ }^{*} \bar{x}, \mu g \cdot \mathrm{mL}^{-1}\end{array}$} & \multirow[b]{2}{*}{$\mathrm{SD}, \mu \mathrm{g} \cdot \mathrm{mL}^{-1}$} & \multirow[b]{2}{*}{$\frac{S D}{\sqrt{n}}, \boldsymbol{\mu g} \cdot \mathrm{mL}^{-1}$} & \multirow[b]{2}{*}{$\bar{x} \pm \frac{t \cdot S D}{\sqrt{n}}, \boldsymbol{\mu g} \cdot \mathbf{m L}^{-1}$} & \multirow[b]{2}{*}{ RSD\% } \\
\hline$\mu \mathrm{M}$ & $\mu \mathrm{g} \cdot \mathrm{mL}^{-1}$ & & & & & \\
\hline 0.1 & 0.0494 & 0.0501 & 0.00120 & 0.00054 & $0.0501 \pm 0.00148$ & 2.4 \\
\hline 0.2 & 0.0988 & 0.1094 & 0.00252 & 0.00113 & $0.1094 \pm 0.00313$ & 2.3 \\
\hline 0.3 & 0.1482 & 0.1534 & 0.00337 & 0.00151 & $0.1534 \pm 0.00418$ & 2.2 \\
\hline 0.4 & 0.1976 & 0.2138 & 0.00449 & 0.00201 & $0.2138 \pm 0.00557$ & 2.1 \\
\hline 0.8 & 0.3951 & 0.4008 & 0.00842 & 0.00376 & $0.4008 \pm 0.01045$ & 2.1 \\
\hline 1.0 & 0.4939 & 0.5162 & 0.01032 & 0.00462 & $0.5162 \pm 0.01282$ & 2.0 \\
\hline 2.0 & 0.9878 & 1.0252 & 0.02050 & 0.00917 & $1.0252 \pm 0.02545$ & 2.0 \\
\hline 4.0 & 1.9756 & 1.9509 & 0.03707 & 0.01658 & $1.9509 \pm 0.04760$ & 1.9 \\
\hline 8.0 & 3.9512 & 3.8750 & 0.06975 & 0.03119 & $3.8750 \pm 0.08659$ & 1.8 \\
\hline 12 & 5.9268 & 5.9089 & 0.09454 & 0.04228 & $5.9089 \pm 0.11737$ & 1.6 \\
\hline 16 & 7.9024 & 7.8605 & 0.12576 & 0.05625 & $7.8605 \pm 0.15614$ & 1.6 \\
\hline 20 & 9.8780 & 9.8944 & 0.13852 & 0.06195 & $9.8944 \pm 0.17197$ & 1.4 \\
\hline 22 & 10.8658 & 10.9115 & 0.14185 & 0.06344 & $10.9115 \pm 0.17610$ & 1.3 \\
\hline 24 & 11.8536 & 11.9009 & 0.15471 & 0.06918 & $11.9009 \pm 0.19207$ & 1.3 \\
\hline 26 & 12.8414 & 12.8355 & 0.15402 & 0.06888 & $12.8355 \pm 0.19122$ & 1.2 \\
\hline
\end{tabular}

* $\mathrm{n}=5 \mathrm{t}=2.776$. 


\section{APPLICATIONS}

Many applications for the determination of flucloxacillin in some Syrian pharmaceutical preparations (in presence a same amount of amoxicillin) using differential pulse polarographic analysis on static mercury drop electrode with negative amplitude in Britton Robinson $0.06 \mathrm{M}$ buffer at pH 4.0 according to the optimal conditions were studied. The amount $(\mathrm{m})$ of FLUX in one capsule was calculated from the following relationship: $m=h . m$ ', where: $m^{\prime}$ is the amount of FLUX in capsule calculated according to the regression equation of calibration curve, $\mathrm{h}$ conversion factors are equal to 100 for all pharmaceuticals content 250 $\mathrm{mg} / \mathrm{cap}$. The results of quantitative analysis for FLUX in pharmaceutical preparations were summarized in Tables 3. The proposed method was simple, direct and successfully applied to the determination of FLUX in pharmaceuticals without any interference from amoxicillin and excipients. Average assay ranged between 99.4 to $102.2 \%$. The results obtained by this method agree well with the contents stated on the labels and were validated by HPLC method [7]. Therefore, the presented method can be recommended for routine analysis of FLUX in pharmaceutical formulations.

Table 3: Determination of FLUX in some Syrian pharmaceutical preparations using DPPA on SMDE with negative amplitude in Britton Robinson $0.06 \mathrm{M}$ buffer at pH 4.0 according to the optimal conditions.

\begin{tabular}{|c|c|c|c|c|c|}
\hline Commercial name & $\begin{array}{l}\text { Label Claim of } \\
\text { FLUX \& AMOX, } \\
\text { mg/cap. }\end{array}$ & $\begin{array}{l}\text { *Mean } \pm \text { SD } \\
\text { (as FLUX)r } \\
\text { mg/ cap. }\end{array}$ & RSD\% & Assay \% & $\begin{array}{l}\text { * (Assay\%) } \\
\text { by HPLC }[7]\end{array}$ \\
\hline $\begin{array}{c}\text { Amoxipen capsule, } \\
\text { BARAKAT } \\
\text { pharmaceutical }\end{array}$ & 250 & 249.40 & 2.7 & 99.8 & 99.5 \\
\hline $\begin{array}{c}\text { Amoxam capsule, } \\
\text { IBN HAYYAN }\end{array}$ & 250 & 250.90 & 2.6 & 100.4 & 100.6 \\
\hline $\begin{array}{c}\text { Penifloxam capsule, } \\
\text { APHAMEA }\end{array}$ & 250 & 255.40 & 2.6 & 102.2 & 102.3 \\
\hline $\begin{array}{c}\text { Floxin capsule, } \\
\text { ALBALSAM pharma }\end{array}$ & 250 & 248.40 & 2.7 & 99.4 & 99.4 \\
\hline $\begin{array}{c}\text { Maxipen capsule, } \\
\text { ASIA }\end{array}$ & 250 & 253.00 & 2.6 & 101.2 & 101.1 \\
\hline
\end{tabular}

${ }^{*} \mathrm{n}=5$, Assay $=$ (found mean/label claim) $\times 100$.

\section{Method validation}

The developed method for simultaneous estimation of FLUX has been validated in accordance with the International Conference on Harmonization guidelines (ICH) [19].

\subsection{Selectivity}

Several other components were examined under the conditions that had been optimized for flucloxacillin determination. The results appeared that amoxicillin and ampicillin did not interfere when they present at the same amount with flucloxacillin. While cloxacillin is interfere. 


\subsection{Linearity}

Several aliquots of standard stock solution of FLUX were taken in different $25 \mathrm{~mL}$ volumetric flasks such that their final concentrations were 0.0494-12.8414 $\mu \mathrm{g} \cdot \mathrm{mL}^{-1}\left(0.100-26.000 \mu \mathrm{mol} . \mathrm{L}^{-1}\right)$ for FLUX using DPPA at SMDE in Britton Robinson $0.06 \mathrm{M}$ buffer at $\mathrm{pH}$ 4.0. Linearity equation obtained was: $y=-18.191 x-0.5094$, for the mentioned range $\left(R^{2}=0.9998\right)$.

\subsection{Precision and Accuracy}

The precision and accuracy of proposed method were checked by recovery study by addition of standard drug solution to pre-analyzed sample solution at three different concentration levels (80\%, $100 \%$ and $120 \%)$ within the range of linearity for FLUX. The basic concentration level of sample solution selected for spiking of the FLUX standard solution was $3.951 \mu \mathrm{g} \cdot \mathrm{mL}^{-1}$. The proposed method was validated statistically and through recovery studies, and was successfully applied for the determination of FLUX in pure and dosage forms with percent recoveries ranged from $99.9 \%$ to $101.6 \%$, see Table 4 .

Table 4: Results of recovery studies $(\mathbf{n}=\mathbf{5})$

\begin{tabular}{|c|c|}
\hline Level & Recovery\% \\
\hline $80 \%$ & 100.5 \\
$100 \%$ & 99.9 \\
$120 \%$ & 101.6 \\
\hline
\end{tabular}

\subsection{Repeatability}

The repeatability was evaluated by performing 10 repeat measurements for $3.951 \mu \mathrm{g} \cdot \mathrm{mL}^{-1}$ of FLUX using the studied DPPA at SMDE Britton Robinson $0.06 \mathrm{M}$ buffer at pH 4.0 under the optimum conditions. The found amount of FLUX ( $\overline{\mathbf{X}} \pm$ SD) was $3.971 \pm 0.067 \mu \mathrm{g} \cdot \mathrm{mL}^{-1}$ and the percentage recovery was found to be $100.5 \pm 1.7$ with RSD of 0.017 . These values indicate that the proposed method has high repeatability for FLUX analysis.

\subsection{Sensitivity (limit of detection [LOD] and limit of quantitation [LOQ])}

The sensitivity of the presented method was evaluated by determining the LOD and LOQ. The values of LOD and LOQ for FLUX are 0.0040 and $0.0120 \mu \mathrm{g} \cdot \mathrm{mL}^{-1}$, respectively.

\subsection{Robustness}

The robustness of the method adopted is demonstrated by the constancy of the current peak $\left(\mathrm{I}_{\mathrm{p}}\right)$ with the deliberated minor change in the experimental parameters such as the change in the concentration of excipients, temperature $\left(25 \pm 5^{\circ} \mathrm{C}\right), \mathrm{pH}(4.0 \pm 0.20)$, and $C_{\text {elect }}(0.06 \pm 10 \%$ mol.L-1 $)$ and reaction waiting time (10 $\mathrm{min}$ ), see Table 5. This table indicates that the robustness of the proposed method was good ( $I_{p}$ was measured and assay was calculated for five times).

\subsection{Specificity}

The specificity of the method was ascertained by analyzing standard FLUX in presence of excipients. These findings prove that the suggested methods are specific for determination of the investigated drugs without interference from the co-formulated adjuvants. 
Table5: Robustness of the proposed DPPA method at SMDE for determination of flucloxacillin.

\begin{tabular}{|c|c|}
\hline $\begin{array}{c}\text { Experimental parameter } \\
\text { variation }\end{array}$ & Average recovery (\%) * \\
\cline { 2 - 2 } & $\mathrm{C}_{\mathrm{FLUX}}=3.951 \mu \mathrm{g} \cdot \mathrm{mL}^{-1}$ \\
\hline $20^{\circ} \mathrm{C}$ & 99.8 \\
$25^{\circ} \mathrm{C}$ & 100.5 \\
$30^{\circ} \mathrm{C}$ & 100.6 \\
\hline $\mathrm{pH}$ & \\
3.8 & 99.8 \\
4.2 & 100.2 \\
\hline $\mathrm{C}_{\mathrm{Britton} \mathrm{Robinson}}$ & \\
$0.054 \mathrm{~mol} / \mathrm{L}$ & 99.4 \\
$0.066 \mathrm{~mol} / \mathrm{L}$ & 100.3 \\
\hline reaction time & \\
$10 \mathrm{~min}$ & 99.7 \\
30 min & 100.4 \\
$60 \mathrm{~min}$ & 101.6 \\
\hline
\end{tabular}

${ }^{*} n=5$.

\subsection{The homogenization of capsule}

The homogenization of capsule in terms of the weight and the amount of drug was studied. It found that the mean weight capsule was $0.6965 \pm 0.015 \mathrm{~g}$ (i.e. $\pm 2.2 \%$ ), $0.6625 \pm 0.011 \mathrm{~g}$ (i.e. $\pm 1.7 \%$ ), $0.7044 \pm 0.021 \mathrm{~g}$ (i.e. $\pm 3.0 \%), 0.6687 \pm 0.015 \mathrm{~g}$ (i.e. $\pm 2.2 \%$ ) and $0.7116 \pm 0.0098 \mathrm{~g}$ (i.e. $\pm 1.4 \%$ ) for Amoxipen capsule, Amoxam capsule, Penifloxam capsule, Floxin capsule and Maxipen capsule (250 mg/cap). And amount of drug in the capsule was $249.00 \pm 5.2 \mathrm{mg}$ (i.e. $\pm 2.1 \%$ ), $250.70 \pm 5.2 \mathrm{mg}$ (i.e. $\pm 2.1 \%$ ), $253.00 \pm 5.5 \mathrm{mg}$ (i.e. $\pm 2.2 \%$ ), $250.00 \pm$ $4.0 \mathrm{mg}$ (i.e. $\pm 1.6 \%$ ) and $254.00 \pm 3.0 \mathrm{mg}$ (i.e. $\pm 1.2 \%$ ) for Amoxipen capsule, Amoxam capsule, Penifloxam capsule, Floxin capsule and Maxipen capsule (250 mg/cap); which shows that homogeneity of capsule is acceptable.

\section{CONCLUSION}

DPPA of FLUX in pure form and in pharmaceutical preparations using SMDE with Britton Robinson $0.06 \mathrm{M}$ buffer at $\mathrm{pH} 4.0$ according to the optimal conditions was applied. One peak was observed. $I_{\mathrm{p}}$ is linear over the range $0.0494-12.8414 \mu \mathrm{g} \cdot \mathrm{mL}^{-1}\left(0.100-26.000 \mu \mathrm{mol}^{-L^{-1}}\right)$. The relative standard deviation did not exceed $2.4 \%$ for the concentration $0.0494 \mu \mathrm{g} \cdot \mathrm{mL}^{-1}$ of FLUX. Regression analysis showed a good correlation coefficient $\left(R^{2}=0.9998\right)$ between $I_{p}$ and concentration over the mentioned range. The proposed method was successfully applied to the direct analysis of FLUX in pharmaceutical formulations without any interference from excipients and the co-formulated adjuvants with adequate accuracy and sensitivity without any pre-separation such as extraction. 


\section{REFERENCES}

[1] O' Neil, M. J., 2013. The Merck Index - An Encyclopedia of Chemicals, Drugs and Biologicals, Royal Society of Chemistry.

[2] British pharmacopoeia. 2012. The Department of Health. Vol I. London: The Stationary office.

[3] Ritchie, S.R., Rupali, P., Roberts, S.A., Thomas, M.G., 2007. Flucloxacillin treatment of staphylococcus aureus meningitis. Eur J Clin Microbiol Infect Dis. 26: 501-504.

[4] Squellati, J.A., Silva, M.M., Nunez-Vergara, L. J., 1981. Anodic polarographic determination of flucloxacillin. Talanta. 28: 855-856

[5] Amr, L.S., Mohmed, A., Elmosallamya, Hamada M., Killaa, Mohmed M., 2013. Selective potentiometric method for determination of flucloxacillin antibiotic. J Taibah Uni Sci. 7: 195-201.

[6] Liu, H., Wang, H., Sunderl, V.B., 2005. An isocratic ion exchange HPLC method for the simultaneous determination of flucloxacillin and amoxicillin in a pharmaceutical formulation for injection. J Pharma Bio Anal. 37(2): 395-398.

[7] Shanmugasundaram, P., Kamal, R.R., Mohanrangan, J., Devdass, G., Arunadevi, M., Maheswari, R., Vijey Aanandhi, M., 2009. Simultaneous estimation of amoxicillin and flucloxacillin in its combined capsule dosage form by HPLC. Rasayan J chem. 2: 57-60.

[8] Zhou, Q., Ruan, Z., Yuan, H., Juan, B., Xu, D., 2007. RP-HPLC analysis of flucloxacillin in human plasma validation and application to a bioequivalence study. Pharmazie. 62: 101-104.

[9] Roder, B.L., Frimodt-Moller, N., Espersen, E., Rasmussen, S.N., 1995. Dicloxacillin and flucloxacillin: pharmacokinetics, protein binding and serum bactericidal titers in healthy subjects after oral administration. Infection 23: 107-112.

[10] Zhang, M., Moore, G.A., Everts, R., Begg, E.J., 2014. Determination of Total and Free Concentrations of Flucloxacillin and Cefazolin in Human Plasma by Liquid Chromatography/Tandem Mass Spectrometry. J Anal Bioanal Tech 5(1): 2-9.

[11] Huang C, Gao J, Miao L (2012) Simultaneous determination of flucloxacillin and ampicillin in human plasma by ultra-performance liquid chromatography tandem mass spectrometry and subsequent application to a clinical study in healthy Chinese volunteers. J Pharm Biomed Anal 59: 157-161.

[12] Worlako Klu, M., Selorm Addy, B., Mintah D.N., 2016. A Simple Validated Rp- HPLC method for the analysis of flucloxacillin sodium in capsule dosage form, World J Pharm Pharma Sci. 5(4): 499-508.

[13] Dey, S.A., Ratnakar, C.H., Vaithiyanathan, S., Samal, H.B., Reddy, Y.V., Krishna, Y.B., Reddy, A., Kumar, G.N., Mohapatra, S., 2010. Spectrophotometric method developed for the estimation of flucloxacilin in bulk and dosage form using UV-Vis spectrophotometric method, Int J Pharma and Bio Sci. 1(4): 35-42.

[14] Singh, G.R., Manirul, H.S., Shanker, P., 2009. A Sensitive validated spectrophotometric method for the determination of flucloxacillin sodium, E-J of Chem. 6(S1): 397-405.

[15] El-Mammli, M.Y., 2003. Spectrophotometric determination of flucloxacillin in pharmaceutical preparations using some nitrophenols as a complexing agent, Spec Acta Part A: Mole and Bio Spec. 59(4): 771-776. 
[16] Vijayalakshmi, R., Sowjanya, D., Archana, S., Dhanaraju, M.D., 2014. Application of extractive spectrophotometric methods for the determination of flucloxacillin and trandolapril using bromocresol green, Asian J Pharma and Clin Res. 7(4): 216-218.

[17] Everett, J. R., Jennings, K., and Woodnutt, G. 1985. 19F NMR spectroscopy study of the metabolites of flucloxacillin in rat urine. J. Pharm. Pharmacol. 37: 869-873.

[18] Anderson, J.E., Bond, A. M., Jones, R. D., 1981. Differential Pulse Polarography at the Static Mercury Drop Electrode, Anal. Chem. 53 (7): 1016-1020.

[19] ICH: Proceedings of the International Conference on Harmonization of Technical Requirement of Registration of Pharmaceuticals for Human Use (ICH Harmonized Tripartite Guidelines), 2005. 